\title{
Między spotkaniem a konfliktem. Filozofia przyrody i przyrodoznawstwo w ujęciu przedstawicieli myśli żydowskiej z XVI i XVII wieku
}

Słowa kluczowe: żydowska filozofia przyrody; nowożytne przyrodoznawstwo; Juda Loew; Dawid Gans; Józef Solomon Delmedigo; Tobiasz Cohn

\section{Wprowadzenie}

W opracowaniach dotyczących zaangażowania Żydów w europejskie badania naukowe w okresie nowożytnym na przełomie XVI i XVII w. podkreśla się fakt ich przynależności do niejako dwóch światów: kręgu kultury i nauki, które wypracowały nowe koncepcje za pomocą nowej metodologii, oraz środowiska tradycji i religii żydowskiej². Związane

${ }^{1}$ Instytut Filozofii, Katedra Filozofii Przyrodoznawstwa, Uniwersytet Kardynała Stefana Wyszyńskiego w Warszawie, e-mail: a.swiezynski@uksw.edu.pl, ORCID: 00000003-0430-4530.

2 Zob. H. Friedenwald, Jewish Physicians in Italy: Their Relation to the Papal and Italian States, "Publications of the American Jewish Historical Society" 1922, vol. 28, s. 133-211; A.Y. Reed, Was there science in ancient Judaism? Historical and cross-cultural reflections on "religion" and "science", "Studies in Religion/Sciences Religieuses" 2007, vol. 36, no. 3-4, s. 461-495; D.B. Ruderman, Jewish Thought and Scientific Discovery in Early Modern Europe, Detroit 2001, s. 54-60; N.M. Samuelson, Jewish Faith and Modern Science: On the Death and Rebirth of Jewish Philosophy, Lanham 2009, s. 3-103. 
z tym trudności były podobne do problemów napotkanych przez tradycjonalistycznie nastawionych chrześcijan, choć w przypadku przedstawicieli środowiska żydowskiego pojawił się dodatkowy element w postaci kryzysu tożsamości. Tradycyjne wierzenia i praktyki religijne były w istocie czynnikami budującymi życie oraz specyfikę społeczności żydowskiej i uzasadniały jej charakterystyczną odrębność. Dlatego w przypadku przedstawicieli judaizmu kryzys, który pojawiłby się $w$ tej sferze, mógłby doprowadzić do kryzysu narodowej tożsamości żydowskiej. Prawdą jest, że we wspomnianym okresie filozofia przyrody oraz formująca się dopiero nowożytna nauka raczej rzadko wywoływały postawy skrajnego racjonalizmu, który byłby w stanie zagrozić żydowskim wierzeniom. Niemniej można mówić o stopniowym narastaniu konfliktu światopoglądowego, a w konsekwencji społecznego między tradycyjnie nastawioną społecznością żydowską i postępową społecznością nieżydowską, który był kolejnym wcieleniem wcześniejszego konfliktu polityczno-kulturowego wyrażającego się w ostracyzmie i prześladowaniach Żydów w XV w., m.in. w Hiszpanii, Portugalii i Francji. Zatem spotkanie Żydów i chrześcijan często rodziło konflikt, a spotkanie tradycji żydowskiej i nowożytnej filozofii i nauki podsycało go jeszcze bardziej.

Jednak dla wielu myślicieli żydowskich była to sytuacja, którą usiłowali zmienić, przezwyciężając wzajemną obcość i wrogość, podejmując dialog, szukając tego, co może zbliżać i łączyć. Dlatego właśnie w filozofii przyrody, a następnie formujących się naukach przyrodniczych upatrywali możliwości przezwyciężenia stanu konfliktu przez spotkanie się na gruncie nauki uczonych wywodzących się z obu kręgów kulturowych.

Oczywiście w praktyce nie było to łatwe, nie tylko z powodu wzajemnych uprzedzeń i zranień, ale także z uwagi na ambiwalentny stosunek judaizmu do naukowego poznawania świata. Stosunek myślicieli żydowskich do powstającej nowożytnej nauki i metody naukowej dobrze charakteryzuje triada: napięcie - aspiracje - tożsamość. Napięcie dotyczy sytuacji polityczno-społecznej związanej z trudnymi relacjami istniejącymi między społecznością żydowską a nieżydowskimi mieszkańcami XVI- i XVII-wiecznej Europy. Aspiracje wskazują na pragnienie i dążenie znacznej grupy przedstawicieli judaizmu do przełamania izolacji i uzyskania statusu społecznego, który umożliwiałby im znalezienie się w gronie ówczesnych elit intelektualnych oraz uzyskanie szacunku, jakim darzy się ludzi wykształconych. Wreszcie tożsamość oznacza narastający problem sposobu określenia się zarówno wobec „swoich”, jak i względem „obcych” w kontekście własnej tradycji religijno-kulturowej, a także określenie stopnia jej zobowiązywalności we własnym życiu. 
Między spotkaniem a konfliktem. Filozofia przyrody i przyrodoznawstwo...

W celu prześledzenia i bliższego ukazania wspomnianych postaw i towarzyszących im procesów trzeba przyjrzeć się poglądom i działaniom przedstawicieli myśli żydowskiej z XVI i XVII w. Celem artykułu jest zarysowanie stanowisk Judy Loewa, Dawida Gansa, Józefa Solomona Delmedigo i Tobiasza Kohna w kwestii rozumienia filozofii przyrody i nauk przyrodniczych (przyrodoznawstwa) jako miejsca spotkania się i dialogu żydów i chrześcijan. Dokonując wyboru właśnie tych myślicieli żydowskich, posłużyłem się kryterium ich reprezentatywności dla poruszanego zagadnienia oraz znaczeniem, jakie mieli dla procesu zbliżania się do siebie obu społeczności. Nie bez znaczenia pozostaje również to, że choć wszyscy mieli istotne związki z Rzeczpospolitą (przez swoje urodzenie lub zamieszkanie i działalność naukową prowadzoną na jej terenie), pozostają mało znani i są rzadko wspominani w literaturze polskojęzycznej. Warto zatem przywrócić pamięć ich postaci i dokonań, tym bardziej że zagadnienie relacji między nauką a religią oraz wynikające z niego dyskusje światopoglądowe nadal zaprzątają umysły wielu współczesnych przedstawicieli nauki i religii. Chrześcijaństwo bowiem także zmaga się od wieków z problemem konfliktu między różnymi obrazami świata (naukowo-przyrodniczym i teologicznym) i można wskazać w nim stanowiska zarówno otwarte na postęp nauki, jak i fundamentalistycznie broniące dosłownego odczytywania biblijnego przekazu o świecie i człowieku. Pod tym względem nie różni się więc od judaizmu. Ponadto ukazany zostanie pragmatyczny aspekt działalności naukowej, przejawiający się w traktowaniu nauki jako swoistego narzędzia, służącego współtworzeniu wzajemnie przyjaznego intelektualnego klimatu nowożytnej Europy.

\section{Historia divina i historia naturalis - Juda Loew ${ }^{3}$}

Spośród wspomnianych powyżej myślicieli żydowskich najbardziej ambiwalentny stosunek do nauki rodzącej się w okresie nowożytnym przejawiał Juda Loew. Powodem tego była posiadana przez niego wizja rzeczywistości materialnej. Przez określenia „natura”, „porządek na-

\footnotetext{
3 Juda Loew ben Bezalel (Maharal) (ok. 1520-1609) - rabin, filozof, kabalista i matematyk, urodzony w Poznaniu. Był naczelnym rabinem Moraw, Wielkopolski, a następnie Pragi. Więcej na jego temat zob.: A. Mauskopf, Religious Philosophy of the Maharal of Prague, New York 1949; B.Z. Bokser, From the World of the Cabbalah - the Philosophy of Rabbi Judah Loew of Prague, New York 1954; tenże, The Maharal: The Mystical Philosophy of Rabbi Judah Loew of Prague, London 1977; B.L. Sherwin, Mystical Theology and Social Dissent: The Life and Works of Judah Loew of Prague, London-Toronto 1982; Y.D. Shulman, The Maharal of Prague: The story of Rabbi Yehudah Loew, New York 1992; Path of Life. Rabbi Judah Loew ben Bezalel (ca. 1525-1609), A. Putík (red.), Prague 2009; Rabbinic Theology and Jewish Intellectual History. The Great Rabbi Loew of Prague, M. Seidler (red.), London 2012.
} 
turalny”, „naturalna rzeczywistość”, które licznie pojawiają się w jego pismach, odnosił się do fizycznego porządku wszechświata. W świecie przyrody różne zjawiska są połączone ze sobą w logiczny związek przyczyn i skutków, który można racjonalnie wytłumaczyć. Ten porządek nie ma jednak żadnego znaczenia dla relacji między Stwórcą a wszechświatem ani dla uchwycenia istoty świata przez człowieka, z dwóch powodów. Po pierwsze, Bóg stworzył system prawidłowości $\mathrm{w}$ naturze z własnej woli, która jest nieprzenikniona dla umysłu ludzkiego. Po drugie, istnieją zjawiska poza porządkiem naturalnym, które są odchyleniami od ustalonego porządku, czyli cuda. Ponieważ nie można sobie wyobrazić, aby Bóg ustanowił prawa, a następnie uchylił je, tzn. ustanowił porządek, a potem zniszczył go, należy przyjąć, że $\mathrm{w}$ zasadzie porządek naturalny jest trwały $\mathrm{i}$ istotny tylko na tym świecie, podczas gdy w wyższym świecie istnieje inny, „ukryty” porządek. Ten ostatni nie poddaje się badaniom naukowym i nie może zostać odsłonięty na drodze ludzkiego wysiłku obserwacyjnego i intelektualnego, a właśnie on, zdaniem Maharala, zawiera najgłębszą prawdę o rzeczywistości, w której istniejemy4.

Trafną literacką ilustracją faktycznego stosunku Judy Loewa do rodzącej się nauki i kształtującej się $\mathrm{w}$ jego czasach metody naukowego poznawania świata materialnego stanowi jedna $\mathrm{z}$ najstarszych tradycji żydowskich utrwalona w legendzie o Golemie - istocie utworzonej z gliny na kształt postaci ludzkiej, pozbawionej duszy i zdolności porozumiewania się. W najbardziej znanej wersji tej legendy przypisuje się stworzenie Golema właśnie osobie Judy Loewa, który w ten sposób chciał uchronić praskich Żydów, posądzanych o bezbożne praktyki okultystyczne i magiczne, przed atakami ze strony innych mieszkańców Pragi. Golem posiadał nadludzką siłę i był każdorazowo ożywiany przez umieszczanie $\mathrm{w}$ jego ustach kartki $\mathrm{z}$ wypisanym Imieniem Boga lub wypisanie na jego czole słowa emet (hebr. prawda). Tak stworzona istota była jednak niema i bezmyślna, mogła tylko wykonywać polecenia, sama nie mając własnej wolnej woli. Według wspomnianej wersji legendy, rabbi Loew powodował powrót Golema do stanu martwej materii każdorazowo przed rozpoczęciem żydowskiego szabatu. Jednak pewnego razu zapomniał tego zrobić w odpowiednim czasie i Golem zaczął szaleć, niszcząc wszystko, co znalazło się na jego drodze. Ostatecznie udało się opanować groźną sytuację, pozbawiając go życia, ale rabbi Loew nie był już w stanie ponownie go

${ }^{4}$ Por. R.S. Uffenheimer, Maharal's Conception of Law: Antithesis to Natural Law Theory, „Jewish Law Annual” 1987, vol. 6, s. 109-125. 
Między spotkaniem a konfliktem. Filozofia przyrody i przyrodoznawstwo...

ożywić do dalszego działania i umieścił pozostałość po nim na poddaszu praskiej synagogi ${ }^{5}$.

W kontekście poglądów Maharala Golem może zostać uznany za symbol tego, co wiąże się z poznaniem naukowym w rozumieniu praskiego rabina: wrodzonej ograniczoności poznania naukowego (nieświadomość ukrytej i niedostępnej dla nauki głębi badanego stanu rzeczy) oraz trudnej do okiełznania, niebezpiecznej dla człowieka i fascynującej jego umysł siły sprawczej efektów badań naukowych. Dlatego działalność naukowa powinna, zdaniem Loewa, zostać podporządkowana poznaniu religijnemu i stać się niejako „służebnicą” teologii. Oznacza to, że nie można stawiać na równi obu tych rodzajów poznania, a tym bardziej przedkładać poznania naukowego nad poznanie o charakterze religijnym (teologicznym):

Nie jest rzeczą właściwą nazywać «mądrym» kogoś, kto posiada wiedzę o rzeczach materialnych, podobnie jak szewca nie nazywa się «mądrym», nawet jeśli jest to pewien rodzaj mądrości. Dlatego tylko ktoś, kto bada święte sprawy, może zostać nazwany «mądrym»i jedynie to jest prawdziwa mądrość 6 .

Inaczej mówiąc, teologia żydowska stanowi „formę”, która powinna ukształtować „materię” nowożytnej nauki, nadając jej adekwatny dla niej kształt i uniemożliwiając jej w pełni autonomiczne funkcjonowanie, które Loew uznawał za niebezpieczne.

Innym przykładem ilustrującym rozumienie statusu poznania naukowego $\mathrm{w}$ ujęciu praskiego rabina jest jego stosunek do naukowego wyjaśnienia zjawiska zaćmienia Słońca. Loew zestawia ze sobą wyjaśnienie wspomnianego zjawiska podane w Talmudzie i wyjaśnienie zaproponowane przez współczesnych mu astronomów. Pierwsze wyjaśnienie odwołuje się do czterech przyczyn związanych z grzesznymi czynami ludzi: brak modlitwy za zmarłych ze strony żydowskich przywódców religijnych; brak pomocy ze strony mieszkańców miasta dla gwałconej kobiety; homoseksualizm; równoczesne morderstwo dwóch braci. Następnie Loew zastanawia się, jak można utrzymywać podobne stanowisko, skoro na podstawie obserwacji astronomicznych

${ }^{5}$ Zob. C. Bloch, Golem: Legends of the Ghetto of Prague, trans. H. Schneiderman, Vienna 1925; G. Scholem, Die Vorstellung vorm Golem in ihren tellurischen und magischen Beziehungen, [w:] tenże, Zur Kabbala und ihrer Symbolik, Frankfurt am Main 1973, s. 257 i n. Por. H. Lejwik, Der Goylem. A dramatishe poeme in Acht Bilder, New York 1921; B.L. Sherwin, Golem Legend: Origins and Implications, Lanham 1985.

6 J. Loew b. Bazalel, Tif'eret Yisra'el, Jerusalem 1978 [Praga 1599], s. 35. 
wiadomo, że zjawisko zaćmienia Słońca zachodzi wskutek określonego wzajemnego położenia ciał niebieskich, które w dodatku może zostać precyzyjnie przewidziane co do czasu swojego wystąpienia. Odpowiadając, zauważa, że uczonym żydowskim nie chodziło o przyczyny bezpośrednie omawianego zjawiska, które są jasne w świetle ustaleń naukowych. Ich celem było ustalenie przyczyny nadrzędnej. Jego zdaniem, gdyby nie było grzechu na świecie, nie byłoby także zjawiska zaćmienia Słońca. Zaćmienie jest bowiem znakiem niedoskonałości i skazy wszechświata. Gdyby nie ludzki grzech, porządek stworzenia nie dopuszczałby pojawienia się zjawiska zaćmienia. Doskonałość świata stworzonego jest minionym stanem rajskim, który z powodu pojawienia się grzechu przestał istnieć. Loew zaznacza również, że nie wiadomo, dlaczego poszczególny grzech powoduje zjawisko zaćmienia Słońca - jest to niemożliwe do wyjaśnienia z powodu ograniczoności ludzkiego poznania ${ }^{7}$. Zatem oba wyjaśnienia (naukowe i teologiczne) są niewspółmierne i sytuują się na różnych poziomach. W konsekwencji nie może być między nimi konfliktu. Mamy więc $\mathrm{w}$ tym przypadku do czynienia $\mathrm{z}$ różnymi typami wyjaśnień dotyczących zjawisk zachodzących $\mathrm{w}$ naturze. Każde $\mathrm{z}$ nich odnosi się do innej historii ich przebiegu, opisując je odpowiednio jako historia divina i historia naturalis.

Wizja poznania naukowego i poznania religijnego (teologicznego) w ujęciu Loewa ma charakter platoński. Doskonałym, idealnym światem ludzkiego poznania i wiedzy jest religia żydowska, a jej niedoskonałym, dalekim od prawdy odblaskiem pozostaje nauka wraz z jej wyjaśnieniami zjawisk i procesów. Początkowo, przed upadkiem człowieka, posiadał on doskonałą i najwyższą mądrość. Wskutek upadku (grzechu) została ona utracona, niejako zapomniana. Dlatego dawne pokolenia były bliżej prawdy niż obecne i kolejne. Pozostaje jednak nadzieja na odnowienie pierwotnego stanu. To wszystko nie oznacza, że praski rabin odrzuca poznanie naukowe jako niepotrzebne lub całkowicie fałszywe. Domaga się jednak, aby nie stawiano tej wiedzy ponad wiedzą religijną ani nawet ich ze sobą nie porównywano. „Ci, którzy przychodzą jako następcy, nie są równi tym, którzy byli dawniej i byli bliżej Proroków. A dziś, w naszym pokoleniu, które charakteryzuje się niedoskonałością i głupotą, ktoś ośmiela się stanąć i mówić przeciwko świętym, którzy żyli dawniej niż tysiąc lat temu, w ten sposób: „Popatrz na moją metodę i stań się mądry!”. W niejednym miejscu

\footnotetext{
7 Zob. G. Veltri, Renaissance Philosophy in Jewish Garb. Foundations and Challenges in Judaism on the Eve of Modernity, Leiden-Boston 2009, s. 126-127.
} 
Między spotkaniem a konfliktem. Filozofia przyrody i przyrodoznawstwo...

korzysta się z pomocy światowych i bałwochwalczych ksiąg i usiłuje się uleczyć słowa naszych świętych pism wiernych Bogu, uznając je za płytkie i niestałe".

Dalszą konsekwencją opisanego stanowiska jest uznanie przez Loewa, że wiedza naukowa pozostaje potencjalnie dostępna w równym stopniu wszystkim ludziom, niezależnie od wyznawanej przez nich religii. „Dlaczego nazywa się filozofię przyrody mądrością Greków? Wszak, gdy usiłuje się wyjaśniać świat, czyż nie jest tak, że ta mądrość jest mądrością należącą do każdego człowieka?"'. Ta uniwersalność rodzącego się nowożytnego poznania naukowego bierze się stąd, że wszyscy ludzie są równi, gdy chodzi o ich materialną naturę. Jak zauważył Maharal, wszyscy mają głowy, ręce, nogi i inne organy. Natomiast istnieje zasadnicza różnica między Żydami i innymi narodami pod względem ich wewnętrznego, duchowego „wyposażenia”, wynikająca z doświadczeń, statusu i religijnej tradycji Narodu Wybranego. Dlatego Loew był osobiście mało zainteresowany wprost samą nauką i jej osiągnięciami, gdyż na gruncie nauki wspomniana różnica jest nie do uchwycenia, co oznacza, że nauka zaciera wspomnianą różnicę. Niemniej pozostawał $\mathrm{w}$ kontaktach ze środowiskiem intelektualnym XVI-wiecznej Pragi, także za pośrednictwem protektora i mecenasa prowadzonych tam wówczas badań naukowych, Rudolfa II Habsburga, z którym spotkał się osobiście w 1592 r. i odbył długą rozmowę na tematy związane z filozofią przyrody, alchemią i astrologią, którymi cesarz się pasjonował.

Interesujące jest jednak to, że zachowując dystans do nauki, Maharal był jednocześnie świadomy jej aktualnych ustaleń, a także procesu rozwoju poznania naukowego jako zmiennego, podlegającego błędom i w pewnym stopniu warunkowego. W kontekście rozważań nad teorią heliocentryczną Mikołaja Kopernika, którą analizował jako pierwszy ze znanych nam myślicieli żydowskich, zauważył, że wiedza oparta na obserwacji świata materialnego jest z natury rzeczy ułomna, a proponowane $\mathrm{w}$ danym momencie wyjaśnienia mogą $\mathrm{z}$ biegiem czasu okazać się fałszywe lub niekompletne. Zupełnie inaczej ma się rzecz $\mathrm{z}$ wiedzą płynącą $\mathrm{z}$ objawienia religijnego, która jest, jego zdaniem, zawsze pewna i dokładna:

${ }^{8}$ J. Loew ben Bazalel, Be'er ha-Golah, New York 1953 [Praga 1598], s. 3.

${ }_{9}$ Cyt. za: N.J. Efron, Judaism and Science. A Historical Introduction, Greenwood Press, Westport-London 2007, s. 114. 
[...] narody pogańskie nie pragną niczego więcej niż stać się mądrymi według wiedzy astronomicznej, i rzeczywiście stali się oni znawcami w tym zakresie, jak powszechnie wiadomo. Jednak wciąż pojawiają się kolejni, nowi znawcy, którzy wywracają wiedzę, jaką tamci zdobywali z tak wielkim wysiłkiem. Przykładowo, pewien człowiek, znany jako znawca Nowej Astronomii, ma nowy opis wszechświata. W konsekwencji całkowicie zmienił on rozumienie, które mieli wcześniejsi astronomowie, co do ruchu gwiazd i konstelacji i praw niebieskich, i opracował całkowicie nowy model, jakkolwiek podkreśla, że wciąż pozostają pewne problemy, których nie potrafi rozwiązaćc ${ }^{10}$.

Nastawienie Loewa względem nauki nowożytnej charakteryzuje się więc daleko posuniętym sceptycyzmem w przeciwieństwie do postrzegania wiedzy, jaką na temat świata posiadają Żydzi, czerpiąc ją z Tory i komentarzy wielu pokoleń żydowskich uczonych. Choć jednoznacznie nie odrzucał on drogi poznania naukowego, wyrażał wątpliwości co do skuteczności współczesnych mu naukowych poszukiwań z powodu rozmaitości naukowych poglądów i wielości proponowanych rozwiązań:

nie jest nawet stosownym nazywać całe to astronomiczne przedsięwzięcie nauką. Uznanie za naukę należy się tylko temu, co zostało dobrze zrozumiane. $Z$ pewnością nie znajdziesz $\mathrm{w}$ ich «nauce» ani jednej osoby, która pojęła przedmiot tego poznania w całej prawdzie, a cóż za różnica jest pomiędzy wielkim a małym kłamstwem? Prawda nigdy nie może zostać $\mathrm{w}$ ten sposób poznana [...] mądrzy poganie jedynie znają czas ruchu Słońca, Księżyca i planet, ale nie posiadają wnikliwego wyjaśnienia tych zjawisk ${ }^{11}$.

A zatem nauka, jej poszczególne dziedziny (astronomia, geografia, medycyna), mogą być miejscem spotkania, dialogu i współpracy między przedstawicielami judaizmu i innych tradycji religijno-kulturowych, ale jedynie w granicach wyznaczonych przez ich przedmiot materialny, który dla Maharala był wszak ,gorszą monetą”. Natomiast sfera prawdziwej mądrości, zakorzeniona w wiedzy natury religijnej (duchowej), pozostanie w zasięgu wierzących Żydów, którzy jako jedyni mają do niej od wieków pełny dostęp.

${ }^{10}$ J. Loew, Netivot ha-'Olam, Tel Aviv, rozdział 14 (bez numeracji stron i daty wydania; [Praga 1596]).

${ }^{11}$ J. Loew ben Bazalel, Be'er ha-Golah..., dz. cyt., s. 115. 
Między spotkaniem a konfliktem. Filozofia przyrody i przyrodoznawstwo...

\section{„Ekumenicznośćc natury - Dawid Gans ${ }^{12}$}

Zdecydowanie bardziej otwarty stosunek do nauki prezentował uczeń i historiograf Maharala Dawid Gans ${ }^{13}$. Otwartość ta wynikała zapewne z licznych osobistych kontaktów Gansa z ówczesnymi uczonymi, takimi jak Tycho de Brahe, Johannes Kepler i Johannes Müller. Miał bowiem okazję bezpośrednio przyglądać się ich pracy w obserwatorium astronomicznym w Pradze oraz jako gość na zamku cesarza Rudolfa II w Benátky, a także sam, dzięki ich uprzejmości, obserwował niebo, co wywarło na nim ogromne wrażenie. Jak przyznał, widział „,wielkie rzeczy”, których wcześniej niedane było ludziom oglądać, ani o których nie wspominały żadne księgi uczonych zarówno żydowskich, jak i pogańskich ${ }^{14}$. Być może te i im podobne doświadczenia spowodowały, że zajął się przygotowaniem wprowadzeń do astronomii, matematyki, geografii i historii, które były adresowane do uczniów szkół żydowskich i stanowiły odpowiedniki współczesnych podręczników szkolnych. Postawił sobie bowiem za cel rozpowszechnienie i spopularyzowanie wiedzy naukowej wśród środowiska żydowskiego, co było swoistym precedensem w tej społeczności.

W przekonaniu Gansa drogi ludzkiego poznania odnoszące się do dwóch grup zdarzeń, o który wspominał Maharal (historia divina i historia naturalis), są ze sobą ściśle złączone przez fakt jedności natury, w której się realizują. Dlatego poszczególne dziedziny poznania naukowego mogą stać się rodzajem lingua franca - wspólnym językiem dla Żydów i chrześcijan stanowiącym narzędzie umożliwiające spotkanie się ich intelektualnych elit. Filozofia przyrody i wyłaniająca się z niej nauka są bowiem „ekumeniczne”, ponieważ natura jest w swej istocie „ekumeniczna”. Świadectwem takiego stanu rzeczy były dla Gansa dostrzeżone przez niego zbieżności między kosmologią rabiniczną i teoriami Tycho de Brahe. Podobnie oceniał ustalenia Keplera, jako

${ }^{12}$ Dawid Gans ben Salomon (1541-1613) - żydowski historyk, astronom, geograf i matematyk. Studiował m.in. w akademii rabinicznej w Krakowie u Mosze Isserlesa (Remu), który wysoko cenił naukowe badanie świata, ponieważ uważał, że stwarza ono szansę na ukazanie pełnej chwały dzieła boskiego stworzenia. Zob. więcej: M. Breuer, Modernism and Traditionalism of David Gans, [w:] Jewish Thought in the Sixteenth Century, B.D. Cooperman (red.), Cambridge (Mass.) 1983, s. 49-88; N. Efron, Irenism and Natural Philosophy in Rudolfine Prague: The Case of David Gans, „Science in Context" 1997, vol. 10, no. 4, s. 627-649; A. Neher, Jewish Thought and the Scientific Revolution of the Sixteenth Century: David Gans (1541-1613) and His Times, trans. D. Maisel, Oxford 1986.

${ }_{13}$ Zob. Zemah David. A Chronicle of Jewish and World History (Prague, 1592), M. Breuer (red.), Jerusalem 1983, s. $145 \mathrm{nn}$.

${ }_{14}$ Zob. N.J. Efron, Judaism and Science. A Historical Introduction..., dz. cyt., s. $118-119$. 
przekraczające różnice istniejące w poszczególnych religijnych obrazach świata ${ }^{15}$. Jednocześnie podkreślał doniosłe znaczenie żydowskiej proweniencji współczesnych mu ustaleń astronomicznych, które jego zdaniem sięgają korzeniami działalności starożytnych postaci biblijnych:

Adam był wybitnym astronomem [...] także Józef [Egipski] napisał, że kiedy Abraham udał się z powodu głodu do Egiptu, nauczał tam astronomii i matematyki i był podziwiany przez Egipcjan za swoją nadzwyczajną mądrość $\mathrm{w}$ obu tych dziedzinach [...]. Z kolei Abraham przekazał tę wiedzę swojemu synowi Izaakowi i wnukowi Jakubowi. [...] Egipcjanie zostali nauczeni matematyki i inżynierii wraz z astronomią przez Jakuba i jego synów, gdy ci przybyli i osiedlili się w Egipcie. [...] $\mathrm{Z}$ kolei Grecy nauczyli się tego wszystkiego od Egipcjan $[\ldots]^{16}$.

Gans pozostawał jednak świadomy tego, że w jego czasach znajomość astronomii w środowisku żydowskim jest bardzo słaba. Dlatego postulował, aby zmienić ten stan rzeczy wśród społeczności żydowskiej i dzięki temu stać się równorzędnymi partnerami w kontaktach z intelektualną elitą nowożytnej Europy: „Co zrobimy wówczas, gdy ci uczeni pochodzący z innych narodów zapytają nas o racje leżące u podstaw interkalacji kalendarza - a dla nich to, że otrzymaliśmy te mądrość [od Boga], nie jest wystarczającym argumentem. Czy jest dla nas właściwym [...] okazać się niemymi, którzy nie są w stanie otworzyć swych ust?"17.

Oprócz tego argumentu na rzecz poznawania świata na drodze badań naukowych Gans przekonywał, że studiowanie astronomii umożliwia lepsze zrozumienie Bożej wszechmocy, prowadzi do wniosku, że musi istnieć Najwyższa Przyczyna złożoności wszechświata oraz jest wprost nakazane przez Torę, gdyż jest to droga do pełniejszego poznania zamysłów i dzieł Boga. Można zatem wnioskować, że dla Gansa przedsięwzięcie naukowe było także działaniem o charakterze religijnym, w którym przez poznawanie natury wyraża się szacunek i uwielbienie dla jej Stwórcy. Z tego powodu wydaje się zasadne uznanie praskiego uczonego za prekursora współcześnie rozwijanej (choć na gruncie chrześcijańskim) teologii nauki ${ }^{18}$.

${ }^{15}$ Zob. J. Brown, New Heavens and a New Earth: The Jewish Reception of Copernican Thought, Oxford 2013, s. 55-57.

${ }^{16}$ D. Gans, Nehmad Vena'im, Jessnitz 1743, s. 8a-b.

17 Tamże, s. 10a

${ }^{18}$ Na temat teologii nauki zob. przykładowo: Teologia nauki, J. Mączka, P. Urbańczyk (red.), Kraków 2015. 
Między spotkaniem a konfliktem. Filozofia przyrody i przyrodoznawstwo...

Niewątpliwie działalność Dawida Gansa miała charakter apologetyczny na rzecz obrony żydowskiego pierwszeństwa w historii rozwoju nauki. Niejednokrotnie starał się ukazywać naukowe ustalenia współczesnych mu uczonych jako potwierdzenia opinii wypowiadanych już dawniej przez nauczycieli żydowskich. Należy jednak zauważyć, że potrafił odnosić się do nich także krytycznie w świetle aktualnych wyników badań, wykazując nieścisłości lub błędy w ich rozumowaniu, aczkolwiek nie umniejszając ich zasług:

wszyscy dawni mędrcy Izraela i pogańscy byli o tym przekonani [że świat jest w połowie lądem, a w połowie oceanem, który go otacza], włączając Abrahama Ibn Ezrę [...]. Była to także opinia wielkiego astronoma Abrahama bar Chiji, tak samo jak Izraeliego [...]. Jednak mamy obecnie jasne świadectwo, które nakazuje nam odrzucić te poglądy [...] i nie powinno być niczym zaskakującym, że w wielu miejscach słowa naszych nauczycieli dotyczące zagadnień astronomicznych i geograficznych są sprzeczne i trudne do wyjaśnienia, gdyż posługiwali się oni językiem metaforycznym lub zagadkowym $[\ldots]^{19}$.

Z pewnością wizja Gansa dotycząca nauki jako miejsca spotkania między uczonymi żydowskimi i nieżydowskimi była nową i śmiałą propozycją na tle dotychczasowych propozycji zmierzających do zachowania separacji między mądrością Żydów i wiedzą pogan. Trzeba jednak podkreślić, że w swoim głównym dziele (Nehmad Vena'im - Zachwycajacy i przyjemny), we fragmencie poświęconym historii astronomii, Gans oddzielił historię Żydów od historii innych narodów, zestawiając je paralelnie. Nie zdecydował się więc na ich połączenie i zmieszanie, lecz pozostawił je jako historie w pewien sposób odrębne. Można w tym zabiegu kompozycyjnym dopatrywać się wpływu jego mistrza Maharala, którego idea dwóch historii pozostała dla Gansa aktualna, choć w postaci zmodyfikowanej przez tego ostatniego. W nowej wersji dochodzi do spotkania obu historii, ale Gans świadomie chroni integralność każdej z nich, aby żadnej nie zniszczyćc ${ }^{20}$.

${ }^{19}$ D. Gans, Nehmad Vena'im...., dz. cyt., 25a.

${ }^{20}$ Por. D.B. Rudermann, Jewish Thought and Scientific Discovery..., dz. cyt., s. 84-87. 


\section{Postulat zgodności teorii z rzeczywistością - Józef Solomon Delmedigo ${ }^{21}$}

Pośmiertne losy Judy Loewa, Dawida Gansa oraz Józefa Solomona Delmedigo, niezależnie od dzielących dwóch pierwszych i trzeciego z nich okresów historycznych, na których przypadły lata ich życia, łączy fakt, że wszyscy trzej zostali pogrzebani na tym samym żydowskim cmentarzu w Pradze, a ich groby stanowią obecnie jedną $\mathrm{z}$ atrakcji turystycznych tego miasta. Delmedigo należy jednak już do kolejnego pokolenia żydowskich uczonych, których droga intelektualna biegła m.in. przez uniwersytety włoskie. Podobnie jak Dawid Gans w Pradze zetknął się z J. Keplerem, tak Józef Delmedigo miał niezwykłą okazję osobiście spotkać w Padwie jednego z największych uczonych nowożytności, Galileusza, i to w momencie, gdy ten dokonywał słynnych pierwszych obserwacji teleskopowych:

mój nauczyciel Galileusz potwierdził, że obserwował Marsa w bliskim położeniu od Ziemi i dostrzegł, że jego światło jest znacznie mocniejsze niż światło Jowisza, mimo że Mars jest od niego mniejszy. Rzeczywiście, jego światło było tak silne, że nie mógł patrzeć na niego przez tubę. Poprosiłem go o pozwolenie na przyjrzenie się temu przez teleskop, i to, co zobaczyłem, wydało mi się raczej wydłużone, a nie owalne [...]. Jakkolwiek Jowisz był owalny, a Saturn [...] jajowaty w kształcie. Tak więc [...] należy wywnioskować, że wszystkie one [planety] uzyskują swoje światło ze Słońca $[\ldots]^{22}$.

Ten ważny epizod z życia Józefa Delmedigo skłania do przypuszczenia, że mógł on, podobnie jak inni uczniowie Galileusza, w jakimś stopniu uczestniczyć aktywnie (a być może nawet odkrywczo) w obserwacjach i badaniach prowadzonych przez włoskiego uczonego, tym bardziej że wspomina, iż „my”, tzn. studenci Galileusza, „zwykliśmy często spoglądać [na niebo] przez szkło teleskopu”23.

${ }^{21}$ Józef Solomon Delmedigo (1591-1655) - żydowski fizyk, matematyk, filozof i teoretyk muzyki. Był m.in. nadwornym lekarzem księcia Krzysztofa Radziwiłła. Więcej na jego temat zob.: G. Alter, Two Renaissance Astronomers. David Gans and Joseph Delmedigo (Rozpravy Ceskoslovenské Akademie Vëd, t. 68), Praha 1958; I. Barzilay, Yoseph Shlomo Delmedigo (Yashar of Candia), Brill, Leiden 1974; J. Adler, Joseph Solomon Delmedigo: Student of Galileo, Teacher of Spinoza, „Intellectual History Review" 2013, vol. 23, no. 1, s. 141-157.

${ }^{22}$ Y.S. Delmedigo, Sefer Elim, Amsterdam 1628-1629, s. 300.

${ }^{23}$ Zob. S. Gulizia, The Paduan Rebbi. A Note on Galileo's Household and Mediterranean Science in the Seventeenth Century, „Philosophical Readings” 2015, vol. 7, no. 3, s. $43-52$. 
Między spotkaniem a konfliktem. Filozofia przyrody i przyrodoznawstwo...

Empiryczne ukierunkowanie poznania, które jest typowe dla nauk przyrodniczych, oznaczało dla Józefa Delmedigo podporządkowanie twierdzeń filozofii przyrody doświadczeniu, które uznał za jedyne źródło pewności. Wszelka wiedza o świecie powinna zostać oparta na danych pochodzących z doświadczenia oraz wnioskach wynikających z ustaleń nauk ścisłych. Przykładowo, teoria Kopernika zawiera lepszy opis wszechświata, ponieważ lepiej wyjaśnia obserwowane zjawiska. Jako uzasadnienie takiego stanowiska Delmedigo przytaczał wspomniane obserwacje jasności planet, której natężenie uzależniał zgodnie z modelem heliocentrycznym - od odległości planet od Słońca oraz od ich położenia względem Ziemi. Ponadto zwracał uwagę na błędy poprzedników polskiego astronoma (Arystotelesa i Ptolemeusza), którzy, zdaniem Delmedigo, nie przywiązywali wystarczającej wagi do precyzyjnych obserwacji nieba. „Nie chcemy mieć nic wspólnego z tymi, którzy przymykają oczy i wolą jedynie podążać za innymi, jak gdyby ci byli oznajmiającymi słowa samego Boga. Ktoś taki jest daleko od tego, aby uznać go za prawdziwego filozofa"24. Należy więc zrezygnować z tez, które pozostają w sprzeczności z ustaleniami nauk empirycznych, np. z tezy o istnieniu niematerialnych poruszycieli ciał niebieskich. Obserwacje wskazują bowiem na materialną jedność świata i brak jakościowej różnicy między materią ziemską i materią ciał niebieskich. Materia wraz ze swymi jakościami i własnościami jest wyłącznym przedmiotem poznania.

Tak radykalnie sformułowana teza naturalizmu epistemologicznego i metodologicznego w konsekwencji doprowadziła Delmedigo do przekonania, że jedynie związek z empirią stwarza myśli żydowskiej szansę ciągłego postępu adekwatnego do rozwoju nauk ścisłych. Dlatego nie mógł zgodzić się na ciasnotę umysłową i zachowawczość środowiska żydowskiego w Amsterdamie, gdzie opublikowano jego najważniejsze dzieło (Sefer Elim - Księga Palm) w ocenzurowanej wersji:

ci źli, głupi ludzie powinni uświadomić sobie, że wola nie może zapanować nad siłą ducha jak właściciel nad swoim niewolnikiem, ale jedynie jak król nad swoim poddanym. [...] Niekiedy w duszy mogą pojawić się myśli tak silne, że wola nie jest w stanie ich rozproszyć. [...] Jak można potępić tego, kto nie chce uwierzyć temu, [...] przeciwko czego niemożliwości rozsądek protestuje? ${ }^{25}$

${ }^{24}$ Y.S. Delmedigo, Sefer Elim..., dz. cyt., s. 151.

${ }^{25}$ Cyt. za: D. Swetschinski, Reluctant Cosmopolitans: The Portuguese Jews in Seventeenth-Century Amsterdam, Oxford 2004, s. 264. 
Delmedigo z pozycji empiryzmu zakwestionował zarówno arystotelesowski racjonalizm, jak i kabalistyczny irracjonalizm ${ }^{26}$. Uważał, że nie należy zniekształcać rzeczywistości, aby dopasować ją do teorii Arystotelesa, ale teoria powinna zgadzać się z rzeczywistością. „Musisz uświadomić sobie, że Arystoteles był tylko człowiekiem, a nie Bogiem. Dlatego nie możesz zawsze polegać na nim bezkrytycznie"27. Z kolei przykładem dystansu, z jakim odnosił się do wszelkich „cudowności” i „niezwykłości”, jest sceptyczne stanowisko, jakie zajął w czasie swojego pobytu w Polsce wobec przypadku „cudownego dziecka” z Gródka, ujawniając następnie towarzyszące temu oszustwo ${ }^{28}$. Jednocześnie wyraźnie odseparował od siebie trzy obszary ludzkiej kultury, w ramach których można mówić o uzyskiwaniu określonego rodzaju prawdy o rzeczywistości: wiedza wynikająca z doświadczenia; mniemanie wynikające $\mathrm{z}$ myślenia o rzeczach i zdarzeniach; wiara oparta na tradycji religijnej. „Dzięki wiedzy poznajemy, dzięki myśli uzyskujemy przekonania, a dzięki ufności możemy wierzyć”29. Niemniej nawet sfera ludzkiej wiary, jako oparta na tradycji, powinna być osadzona na historycznych świadectwach mających status swoistego „empirycznego dowodu”.

Pozostaje faktem, że Józef Delmedigo był powszechnie akceptowany i doceniany jako badacz natury nie tylko w środowiskach intelektualnych chrześcijańskiej Europy ${ }^{30}$, ale także przez środowiska żydowskie, i to z dwóch powodów: jego osiągnięć jako filozofa przyrody, matematyka i lekarza oraz reputacji i uznania, jakim cieszył się na dworach europejskich. Można nawet stwierdzić, że Delmedigo był dla dużej części społeczności żydowskiej powodem do chluby i dumy, a jego działalność wiązano $\mathrm{z}$ nadzieją na przełamanie niechęci wobec Żydów, o czym mogą świadczyć słowa, które znalazły się we wstępie do Sefer Elim, autorstwa Simone Luzzatto, powszechnie szanowanego rabina Wenecji:

${ }^{26}$ Zob. J. Ochman, Średniowieczna filozofia żydowska (Historia filozofii żydowskiej, t. 2), Kraków 1995, s. 263-264.

27 Y.S. Delmedigo, Sefer Elim..., dz. cyt., s. 433.

${ }^{28}$ Zob. D. Ruderman, Three Contemporary Perceptions of a Polish Wunderkind of the Seventeenth Century, „Association for Jewish Studies Review” 1979, vol. 4, s. 143-163.

${ }^{29}$ Y.S. Delmedigo, Sefer Elim..., dz. cyt., s. 88.

${ }^{30}$ Łączyła go bliska przyjaźń m.in. z polskim uczonym i duchownym Janem Brożkiem (1585-1652). W kontekście ciągłych podróży naukowych, które Delmedigo odbywał między ówczesnymi ośrodkami wiedzy, wydaje się on raczej „Dedalowskim” rzemieślnikiem niż Żydem z diaspory. Por. J. Adler, J. S. Delmedigo and the Liquid-inGlass Thermometer, „Annals of Science” 1997, vol. 5, s. 293-299. 
Między spotkaniem a konfliktem. Filozofia przyrody i przyrodoznawstwo...

Moje serce raduje się i mój umysł napawa się tą cudowną wiedzą; usta tych, którzy, patrząc na nas, mówią, że brakuje nam nauki i rozumu, zostaną zapieczętowane. Dziś greccy i rzymscy uczeni powiedzą: «Oni mają te same umysły co my i pokazali swoją prawdziwą wartość». Tekst ten należy przetłumaczyć, ponieważ on przyniesie nam prestiż. Modlę się do Boga w miejscu Jego zamieszkania, aby autor został uznany i chwalony, a wiedza o Bogu rozprzestrzeniała się po całej ziemi! ${ }^{31}$

\section{Racjonalne dociekanie przyczyn naturalnych - Tobiasz $\mathrm{Kohn}^{32}$}

Tobiasz Kohn był prawdopodobnie jednym z pierwszych żydowskich studentów, którzy usiłowali zdobyć wykształcenie w zakresie medycyny na niemieckich uniwersytetach (konkretnie we Frankfurcie nad Odrą), lecz bezskutecznie. Chłodne, a nawet wrogie przyjęcie, z jakim spotkał się tam ze strony władz i studentów nieżydowskiego pochodzenia oraz wprost wyrażana niechęć względem jego osoby skłoniły go do przeniesienia się do znacznie bardziej tolerancyjnej Padwy $^{33}$. Jednak pamięć o przykrych doświadczeniach pozostawiła w nim głęboki ślad, który sprawił, że stały się one głównym motywem napisania pracy o charakterze encyklopedycznym - Ma'aseh Tuvviyah (Dzieła Tobiasza), zawierającej szerokie spektrum wiedzy, zwłaszcza z zakresu medycyny:

I niekiedy bluźnili nam, mówiąc do nas: Gdzie jest wasza mądrość i wiedza? Została wam odebrana i dana nam. Ponieważ wy już nic nie wiecie; nie jesteście ludźmi uczonymi. [...] I wówczas mój duch zapłonął gorliwością, gorliwością względem Boga, i przysiągłem sobie, że z Bożą pomocą nie spocznę i nie użyczę snu moim oczom i powiekom moim spoczynku, aż napiszę, z Bożą pomocą, dzieło zawierające mą-

${ }^{31}$ Cyt. za: A. Guetta, Italian Jewry in the Early Modern Era. Essays in Intellectual History, Boston 2014, s. 246 (przypis 26).

32 Tobiasz Kohn (Katz) (1652-1729) - żydowski lekarz i encyklopedysta. Praktykował m.in. na terenie Polski. Więcej na jego temat zob.: M. Bersohn, Tobiasz Kohn. Lekarz polski w XVII wieku, Kraków 1872; A. Levinson, A Medical Cyclopedist of the Seventeenth Century, „Bulletin of the Society of Medical History” Jan. 1917, s. 27-44; J. Ruhräh, Tobias Katz (1652-1729), "American Journal of Diseases of Children" 1934, vol. 47, no. 2, s. 399-401; N. Allan, A Jewish Physician in the Seventeenth Century, "Medical History" 1984, vol. 28, s. 324-328; E. Lepicard, An Alternative to the Cosmic and Mechanic Metaphors for the Human Body? The House Illustration in Ma'aseh Tuviyah (1708), „Medical History” 2008, vol. 52, s. 93-105.

${ }^{33} \mathrm{Na}$ temat stosunku do Żydów i dyskryminacyjnej polityki uniwersytetów europejskich względem nich zob. J. Efron, Medicine and the German Jews: A History, New Haven 2001, s. 34-63. 
drość i wiedzę, będące odpowiedzią dla naszych dręczycieli i pokażę im, że ta mądrość jest dana nie tylko im samym. [...] i że wciąż wśród nas jest obecny człowiek rozumny i światły, który posiada mądrośćc 34 .

Kohn nie tylko praktykował jako medyk, ale także zajmował się medycyną w sposób naukowy, jako badacz. Przykładem jego wnikliwości i rzetelności w tym zakresie są próby opisania symptomów, wyjaśnienia przyczyn i zaproponowania terapii dotyczącej przypadłości kołtuna (Plica polonica) ${ }^{35}$. Swoje ustalenia, które poczynił w trakcie praktyki medycznej na terenie Rzeczpospolitej, rozpoczął od stwierdzenia: „W dociekaniu przyczyny naturalnej i racjonalnej opowiem co widziałem na własne oczy w czasie pobytu w Polsce"36. Odwołanie się przez Kohna do natury i racjonalności nie oznacza, że nie uwzględniał on możliwości wystąpienia innego typu przyczyn (np. działanie czarów), ale po rozważeniu ich doszedł do wniosku, że należy je wykluczyć. Konsekwentnie odżegnywał się też od „nadprzyrodzonych” sposobów zwalczania kołtuna, choć miał świadomość, że są one popularne wśród ludzi, z którymi się zetknął:

ponieważ wiara w czartów jest niemal powszechną, wypowiem więc co myślę o nich. Gdyby nawet wcale nie istnieli szatani, musieli by być stworzeni dla tutejszego kraju, nie masz bowiem ziemi, gdzieby się tak bardzo zajmowano sprawami czartów, oraz amuletami, zaklęciami, wyrazami tajemniczemi i snami, jak pomiędzy ludem tutejszym. Nie chcę bynajmniej należeć do liczby tych, co się podobnemi zajmują bredniami $[\ldots]^{37}$.

$\mathrm{Z}$ kolei, analizując $\mathrm{w}$ innym miejscu koncepcję systemu heliocentrycznego, mocno ją skrytykował, argumentując przeciwko niej, jej autora (Kopernika) zaś nazwał nawet „Synem Szatana”38, co jednak niekoniecznie musiało oznaczać potępienie polskiego astronoma, lecz było być może środkiem ekspresji wyrażającym uznanie dla jego uczoności, swoistym komplementem ${ }^{39}$. Charakterystyczne jest przy tym to, że argumentacja żydowskiego uczonego stanowiła kompilację świadectw obserwacyjnych i fragmentów zaczerpniętych z Biblii,

${ }^{34}$ T. Cohen, Ma'aseh Tuvviyah, Stamparia Bragadina, Venice 1707, s. 25.

${ }^{35}$ Zob. S. Gąsiorowski, Plica polonica, czyli kottun polski w XVI-XVII w., „Rocznik Przemyski” 2013, R. 49, nr 3, s. 12-14.

${ }^{36}$ Cyt. za: M. Bersohn, Tobiasz Kohn..., dz. cyt., s. 16.

37 Tamże, s. 23-24.

${ }^{38}$ Zob. T. Cohen, Ma'aseh Tuvviyah..., dz. cyt. (tytuł rozdziału czwartego).

39 Por. J. Brown, New Heavens and a New Earth..., dz. cyt., s. 96. 
Między spotkaniem a konfliktem. Filozofia przyrody i przyrodoznawstwo...

ale pozostając świadomym złożoności interpretacji tekstu biblijnego, swoje geocentryczne stanowisko uzasadniał ostatecznie na gruncie matematyki i eksperymentu.

Tobiasz Kohn może być postrzegany jako swoisty obrazoburca, który usiłował obalić tradycyjne żydowskie rozumienie przyrody, „,óry” Boga-Stwórcy, i zastąpić je wiedzą wykładaną na współczesnych mu uniwersytetach. W szczególności medycyna była dla niego nową drogą podążania ludzkiej mądrości:

Nie chcę, drogi czytelniku, zmuszać cię do rygorystycznego przestrzegania moich nauk i nakłaniać do pójścia drogami współczesnych lekarzy bez zbaczania na prawo i na lewo; ale prawdą jest, że metoda, którą współcześni lekarze używają z taką stałością i refleksyjną analizą, doprowadziła ich do nowych odkryć [...] w ten sposób oświecili nas, abyśmy mogli w naszych czasach ustanowić praktyczną metodę medycyny $[\ldots]^{40}$.

Jednocześnie wierzył $\mathrm{w}$ to, że wiedza z zakresu nauk przyrodniczych może wzmocnić i zrehabilitować kulturę żydowską. Dlatego jedną z głównych, oryginalnych cech jego encyklopedycznego dzieła była próba skojarzenia „nowych nauk” z tradycyjnym żydowskim postrzeganiem nauki w ogóle, a medycyny w szczególności:

dawni mędrcy nazywali człowieka mikrokosmosem. Było tak we wcześniejszych pokoleniach, kiedy ludzie byli wielkiej postury, a ich siła była potężna, ich życie długie, a ich mądrość głęboka. A kiedy błogosławiony król Salomon dostrzegł w swojej mądrości, że ich moc wygasła, że ich życie się skróciło, a ich mądrość przepadła, porównał człowieka do miasta [...]. A ja, człowiek o małej wartości, postanowiłem w swym sercu dowiedzieć się, jaką korzyć przynosi człowiekowi porównanie go do mikrokosmosu, lub do miasta, albo nawet do małego miasta. Wystarczy, że będzie on niczym jedna z wież lub jeden z domów wewnątrz otoczonego murem miasta, [...], tak jak pokazałem wam we wzorze domu i jego elementów, jak Dom Duszy, albowiem ma niższe, drugie i trzecie poziomy, i strych, i dach na górze, i mury wokół, i zakątki domu. I tak mądrzy lekarze podzielili człowieka na trzy części i obszary, a to jest: głowa, klatka piersiowa i brzuch ${ }^{41}$.

Tak zaprezentowana i rozwinięta przez Kohna metafora (struktura domu jako odpowiednik anatomicznego obrazu człowieka) wraz

${ }^{40}$ Cyt. za: N. Allan, A Jewish Physician...., dz. cyt., s. 328.

${ }^{41}$ T. Cohen, Ma'aseh..., dz. cyt., s. 105a. 
z odniesieniem do mądrości króla Salomona może być postrzegana jako nawiązanie do judaistycznych źródeł wiedzy naukowej. Zauważmy także, iż dom przedstawiony w metaforze, który zgodnie z opisem odpowiada jednej z wież lub domów znajdujących się pośród innych domów otoczonego murem miasta, rodzi skojarzenie z poparciem społeczności żydowskiej, które Tobiasz znalazł w Padwie podczas studiów po swoich trudnych doświadczeniach we Frankfurcie. A zatem tekst sugeruje oryginalną aplikację tradycyjnych źródeł żydowskich, choć jedynie w ich warstwie mądrościowej, a nie religijnej, oraz osobistych doświadczeń autora: osoby, która potrzebowała wsparcia swojej społeczności, aby zostać lekarzem. Gdy nim już został, postawił sobie za cel uzdolnienie umysłowości środowiska żydowskiego do utożsamiania wiedzy raczej z treściami obecnymi we współcześnie drukowanych księgach, niż z zagadkowymi, trudnymi do odczytania znakami obecności i działania Boga w naturze.

\section{Zakończenie}

Dla przywołanych powyżej przedstawicieli myśli żydowskiej filozofia przyrody i przyrodoznawstwo, oprócz niewątpliwie posiadanego przez nie waloru poznawczego, miały także wymiar pragmatyczny. Pragmatyczne podejście do nauki wyrażało się w: 1) dążeniu do przełamania izolacji społeczności żydowskiej przez otwarcie jej na wiedzę z zakresu nauk przyrodniczych; 2) zmierzaniu do uzyskania znaczenia, szacunku i uznania w europejskich środowiskach intelektualnych; 3) poszukiwaniu wsparcia i protekcji u przedstawicieli ówczesnej władzy w związku z realizowaną działalnością naukową oraz jej praktycznymi efektami. Chodziło więc o rozładowanie konfliktów na linii: społeczność żydowska-społeczność chrześcijańska. Ten cel od początku wydawał się trudny do osiągnięcia z powodu zasadniczego dystansu przedstawicieli judaizmu względem rodzącego się nowożytnego przyrodoznawstwa. Ponadto działalności żydowskich uczonych nieodmiennie towarzyszyło uwikłanie uprawianej przez nich filozofii przyrody i przyrodoznawstwa w religijny obraz świata (obecny w judaizmie) i powiązane $\mathrm{z}$ nim zmaganie się o zachowanie tożsamości religijno-kulturowej. A wreszcie, spotkanie z myślicielami chrześcijańskimi i wyłaniającym się z filozofii przyrody naukowym obrazem świata rodziło jeszcze inny konflikt, niż ten dotyczący trudnych wzajemnych relacji z nie-Żydami lub wewnątrz społeczności żydowskiej między „zwolennikami postępu” i „tradycjonalistami”. Chodzi o konflikt najbardziej wewnętrzny, rozgrywający się w sumieniu poszcze- 
Między spotkaniem a konfliktem. Filozofia przyrody i przyrodoznawstwo...

gólnego badacza i zmuszający go do opowiedzenia się za lub w jakimś sensie przeciw własnej tradycji. Autentyczną i zarazem dramatyczną ilustracją takiego stanu rzeczy jest wspomnienie zapisane przez innego przedstawiciela żydowskich fizjologów i lekarzy z przełomu XVI i XVII w., Abrahama Portaleone:

kiedy Bóg chciał mnie ukarać, zachorowałem. Dwa lata temu cała lewa strona mojego ciała stała się jakby martwa i nie mogłem dłużej dotykać ręką do mojej piersi ani chodzić po ulicy, nawet opierając się na lasce, z powodu utraty czucia i zdolności poruszania kończynami. Przeanalizowałem moje postępowanie i zobaczyłem (dzięki Temu, który widzi wszystko), że dodatkowo do moich grzechów, które były liczniejsze niż włosy na mojej głowie, krzyk o moim zaniedbaniu Tory powstał przed obliczem Boga. Poprzez kontakt z dziećmi greckiej mądrości starałem się osiągnąć wielkość przez filozofię i medycynę, które zwabiły mnie miodem swoich słów, abym szukał zbawienia na drogach ciemności i w ten sposób uniemożliwiły mi poświęcenie się dziedzictwu wspólnoty Jakuba, jak to powinienem był czynić. To dlatego Bóg rozgniewał się przeciwko mnie, straszliwe choroby zaciemniły moje dni i pokonały mnie; moje nerwy są zrujnowane, moje westchnienia nie ustają, a wraz z powstaniem goryczy w mojej duszy sen opuścił mnie i nie mogę odzyskać mojej siły. Szczęście mnie opuściło a zwiększył się mój ból [...] $]^{42}$.

Ostatecznie, na sam koniec życia, Portaleone „nawrócił się” i porzucił dalszą działalność naukową, idąc za głosem własnego sumienia. W jego przypadku spotkanie $\mathrm{z}$ nauką i ujawniający się $\mathrm{w}$ tym spotkaniu konflikt wewnętrzny okazały się powodem odrzucenia przeciwnej Torze intelektualnej fascynacji światem, które dla uczonych, takich jak Gans, Delmedigo, Kohn (a w pewnym stopniu także Maharal), oznaczałoby zaprzepaszczenie szansy na realizację ideału współtworzenia przez społeczność żydowską klimatu naukowego nowożytnej Europy. Ich odmienny wybór nie oznacza jednak, że byli od tego wewnętrznego konfliktu całkowicie wolni.

\section{Summary Cooperation and conflict. Philosophy of nature and natural sciences in Jewish thought in the 16th-17th centuries}

Persecution of Jews from the beginning of the 15th century and the need for emigration did not create conditions favorable to the intellectual development

${ }^{42}$ A. Portaleone, Shiltey ha-Gibborym, Mantua 1612 - cyt. za: A. Guetta, Italian Jewry..., dz. cyt., s. 33. 
of Jewish communities. However, the movement caused by them and the creation of intellectual contacts with the non-Jewish community resulted in a partial depressurization of the Jewish intellectual and scientific community. As a result of signaled processes, Jewish thought began to take on an increasingly eclectic and universal character. Some Jewish thinkers were convinced that the philosophy of nature and the emerging science (and medicine in particular) is independent of the religious worldview in the sense that it provides universal knowledge about nature and its regularities. However, some representatives of Jewish thought at the time recognized this "insensitivity" of modern science to religious differences as a basis for discrediting medicine and other fields of science, not because they are false or ineffective, but because they only concern matter and empiricism with their interest and methodology. Analysis of the views of representatives of Jewish thought from the 16th and 17th centuries, such as: Judah Loew, David Gans, Joseph Solomon Delmedigo and Tobias Cohn, allows to show their scientific and philosophical activity as a tool for realizing non-scientific goals, which were: rapprochement and dialogue with representatives of non-Jewish backgrounds in order to prevent mutual hostility, gain the respect and recognition of the then social elite, protect Jewish communities from further persecution. Finally, the idea was to make the Jews remain in the sphere of religious beliefs and cultural traditions while avoiding harmful intellectual and social isolation on the part of the Christian community and to co-create the scientific climate of modern Europe. The developing science was, in the intention of mentioned researchers, to be a tool and at the same time a place for the fulfillment of this ideal.

Keywords: Jewish philosophy of nature; modern natural science; Judah Loew; David Gans; Joseph Solomon Delmedigo; Tobias Cohn 